\title{
Reading Ottoman Sunnism through Islamic History: Approaches toward Yazīd b. Mu'āwiya in Ottoman Historical Writing
}

\author{
Vefa Erginbaş
}

Yazīd b. Mu'āwiya (r. 61-64/68o-683), the second caliph of the Umayyad dynasty, has been a major bone of contention in the sectarian rift between Sunnis and Shi'ites to the present day. Conflicting views about Yazìd are not the product of the modern age of sectarian disputes but are reflections of a historical debate among the Muslim historians and religious scholars regarding Yazid's persona and his actions, and whether one is to love, tolerate, or curse him. There are three major factions on this issue: on the one side, there are those who accept Yazīd as a Muslim king who deserved obedience from his people. In a famous verse in the Quran (4: 59), God asks believers to obey "those in authority" (ūlu l-amr). This verse was used by various rulers throughout the Islamic world to suppress opposition and quell rebellions. According to this view, Muhammad's grandson Husayn's (d. 61/68o) opposition to Yazīd made him a rebel. These people see Yazìd as a Muslim for better or worse and discourage anyone from cursing him based on a hadith of the Prophet Muhammad, which prohibited Muslims from cursing their brethren. On the other side stand those who find in Yazīd's life clear evidence of unbelief as well as debauchery. They emphasize Yazid's direct involvement in the killing of Husayn and members of the family of Muhammad at Karbala. ${ }^{1}$ In between these two groups, there are those who agree on the "wicked" character of Yazīd but see him as a legitimate ruler devoid of religious authority. In this camp are also those who accept Yazĩd's questionable character and allow cursing him because they believe his

1 The earliest source of this episode is Kitāb Maqtal al-Husayn of Abū Mikhnaf (d. 157/774). Abū Mikhnaf's original work is not extant. His work is preserved to a large extent by his transmitter Hishām b. al-Kalbī (d. 204/819). Abū Mikhnaf, Maqtal al-Husayn. In a more recent revision and translation of this work, the editor and translator of Abū Mikhnāf's work argue that this widely circulated version of the Maqtal is unreliable. They suggest using their edition. See Abū Mikhnaf, The event of Taff. This version indeed provides critical comparison with other sources that describe the events at Karbala. Al-Ṭabarī also based his section about Yazīd's caliphate mostly on Abū Mikhnaf. Al-Ṭabarī, The history xix. 
actions made him an unbeliever. Although one could be tempted to identify the first of these groups as Sunnis, and the opposing group as Shi'ites, and label everybody in between as people of fluid confessional identity, the historical evidence makes it difficult to pinpoint rigid boundaries among these groups.

The Sunni-Shi'ite dispute originated in the first civil war in the history of Islam when 'Alī b. Abī Ṭālib (r. 35-40/656-661) and Mu'āwiya (r. 40-6o/661680 ) clashed with each other. Even though neither Sunnism nor Shi'ism was firmly established until after the fourth/tenth century, the murder of Husayn and many of Muhammad's descendants at Karbala in the hands of Yazìd b. Mu'āwiya's governor 'Ubayd Allāh b. Ziyād (d. 67/686) became a cornerstone of Shi'ite grievances from the very early days of the formation of Shi'ism. The Shi'ites, after the sixth imam, Ja'far ibn Muhammad al-Ṣādiq (d. 148/765), opted for dissimulation (taqiyya) in regards to the first three caliphs since 'Alids were not strong enough to establish an independent state. On the other hand, the Umayyads, beginning with Mu'āwiya, demanded public cursing of 'Alī from the pulpits, especially during the Friday prayers. This practice is believed to have continued until the end of Umayyad rule except for a short period when the Umayyad caliph 'Umar ibn 'Abd al-'Azīz (r. 99-101/717-720) banned it. ${ }^{2}$ Even though the cursing of the first three caliphs existed among some branches of Shi'ism, it seems that public cursing was initiated and heavily sponsored by the Safavid Shah Ismā'ìl I (r. 907-930/1501-1524) under the influence of his ghulät (extreme Shi'i) followers. Cursing Yazìd and denigrating the first three caliphs became significant markers of Safavid Shi'ism. Ismācil conveniently used the practice to subdue the Sunni population of Iran. ${ }^{3}$ His successor, Shah Tahmāsb (r. 930-984/1524-1576), is said to have institutionalized this practice, which became a major point of contention in the Ottoman-Safavid struggle. ${ }^{4}$ In the famous Treaty of Amasya (962/1555), the Safavids promised to end the ritual cursing of the first three caliphs, the Prophet's wife 'Á'isha (d. 58/678), and the Prophet's Companions. ${ }^{5}$ This was a promise that they never kept as the tabarräayan continued to flourish under the following Safavid shahs, except during the brief reign of Ismāî̀ II (r. 984-985/1576-1577), who purportedly attempted to revert Iran to Sunnism, with little success. ${ }^{6}$

This chapter looks into the differing approaches toward Yazīd b. Muāwiya as they are reflected in select Ottoman historical sources from the ninth/fif-

2 Al-Ṭabarī, The history xviii, 122-125.

3 Algar, Caliphs and caliphate.

4 On this Safavid invention (tabarrā̄iyān), see Stanfield-Johnson, The tabarra'iyyan 47-71.

5 Newman, Safavid Iran.

6 For an excellent treatment of this episode, see Stewart, The lost biography 177-205. 
teenth until the mid-eleventh/seventeenth century to reveal the nuances of Ottoman Sunnism. It argues that, in its intellectual and cultural manifestations, Ottoman Sunnism had a strong "ahl al-baytist" bent, meaning that it incorporated a strong tradition of love and reverence toward Muhammad's family and descendants (ahl al-bayt).

One cannot, in fact, talk about Yazīd in limbo; to understand Ottoman attitudes toward him and his actions, we should locate him in his historical context, as a member of the Umayyad dynasty. The Umayyads get a critical treatment in the classical Islamic historiography mostly due to the 'Abbasid-era historians' stance toward them. ${ }^{7}$ One can safely argue that the Ottoman intellectuals borrowed similar views from these 'Abbasid historians. It is important to remember, however, that a countertradition to the 'Abbasid one developed, especially in Syria in the third/ninth century, a tradition which espoused the Umayyads, and among them especially Mu'āwiya and Yazìd. Charles Pellat aptly calls this tradition "the Mu'āwiya cult." In a similar vein, the incredibly prolific and influential medieval historian Ibn 'Asākir (d. 571/1175) painstakingly worked to rehabilitate the image of Yazid as a pious man, who deserved the caliphate and who was not personally responsible for the events at Karbala. ${ }^{9}$ Similarly, in the fifth/eleventh century, a Hanbali theologian 'Abd al-Mughith b. Zuhayr al-Harrī (d. 483-484/1091) published a book entitled Fì fad̄àil Yazid (On Yazild's Virtues). ${ }^{10}$ In the following pages I will examine how the Ottomanera historians positioned themselves vis-à-vis the accounts of Yazīd.

7 See Blankenship, The end of the jihad state; Robinson, Islamic historiography; El-Hibri, Reinterpreting Islamic historiography.

8 Pellat, Le culte de Mu'āwiya 53-66. I would like to thank Devin J. Stewart for directing me to this study.

9 Lindsay, Caliphal and moral exemplar? 250-278. Also see Khalek, Early Islamic history reimagined 431-451. Ibn 'Asākir's approach seems to be influenced by his almost "extreme" love for Syria and particularly Damascus, to an extent that Damascus emerges from his Tārīkh as a more important Islamic city than Mecca and Medina. Today, such an approach would be associated with some sort of a "local nationalism," which obviously tainted Ibn 'Asākir's view of the Umayyad caliphate and its contributions to the Islamic history. This work also includes many hadiths of dubious authenticity which foretell the glorious future of Syria as well as the Syrians. For more detail on this and his Tārïkh, see Baş, İbn Asâkir ve Târihu 691-706.

Goldziher, Muslim studies 96. 


\section{Between Confessional Ambiguity and Refashioned Sunnism: Perspectives from the Fourteenth and Fifteenth Centuries}

It is hard to pinpoint Ottoman religious identity in the first century of the empire. It is even harder to tell if there really was a religious policy. As Cemal Kafadar rightly argued, early Ottomans were doxy-naïve and not doxy-minded, living in what he calls the state of "metadoxy."11 Popular Suf tariqas, which were just forming and presenting a quiet "fluid and untidy" view, ${ }^{12}$ as well as a nonstringent religious landscape, dominated the lands of Rum. These religious figures, who presented quite an eclectic world view, propelled the Ottoman expansion into the Balkans. On the other hand, with the territorial expansion in the ninth/fifteenth century came also the institutions such as madrasas and mosques, and a more concerted effort toward defining orthodoxy. One could argue that especially after Mehmed II's reign (r. 848-850/1444-1446, 855886/1451-1481), under various şeyhü'l-islāms, Ottoman religiosity began to be shaped by the religious policies of the Ottoman dynasty. Even though one can clearly talk about a gradual Sunnitization process steered by the Ottoman dynasts and their ulama, there is not enough evidence showing that their efforts successfully transformed the religious feelings and associations of large segments of the society. On the contrary, various heresy trials toward the end of the ninth/fifteenth century, ${ }^{13}$ as well as the popularity of antinomian movements display the resilience on the part of society.

How did the early Ottoman sources treat the succession struggle in early Islam? What can we learn from their treatments about Ottoman Sunnism in its formative stage? What immediately follows answers these questions based on four of the Ottoman writers from the eighth/fourteenth and ninth/fifteenth centuries: Aḥmedī (d. 815/1413), Yazıcıoğlu Meḥmed (d. 855/1451), Şükrullāh (d. after 868/1464), and Enverī. Granted, the first three are poets with clear Sufi associations while Şükrullāh is a historian and statesman, and their works do not fit neatly into one genre. For this reason, the following analysis will focus on what these works have to say on the topic at hand, without taking into close consideration the specifics of their genres.

Ahmedì's most significant work, İskendernāme, is a poetic rendition of the Alexander romance, which was a popular genre in the medieval period, combined with a universal history. ${ }^{14}$ Born around 735/1334, Aḥmedī in middle age

\footnotetext{
11 Kafadar, Between two worlds 76.

12 Kara, Origins of Anatolian Sufism 90.

13 Ocak, Zındıklarve mülhidler.

14 A detailed study of this text can be found in Sawyer, Alexander, history, and piety.
} 
enjoyed the patronage of Süleymān Beg of the central Anatolian Germiyanoğlu dynasty (r. $768-788 / 1367-1386) .{ }^{15}$ He probably started writing his İskendernāme when he was under Süleymān Beg's patronage. Aḥmedī switched allegiances according to the fortunes of the Anatolian beyliks during the tumultuous eighth/fourteenth century; after leaving the service of the Germiyanoğulları, he attached himself to the Aydınoğulları dynasty of southwestern Anatolia, and finally to the House of 'Osmān, which was still a largely unknown entity among intellectuals of the age. In an ironic twist of fate, he ended up presenting his İskendernāme to another Süleymān, Süleymān Çelebi, one of the sons of Bāyezīd I (r. 791-804/1389-1402) and an ultimately unsuccessful contender for the Ottoman throne during the interregnum (804-816/1402-1413) following Bāyezīd's defeat by Tamerlane. ${ }^{16}$ The latter part of Ahmedī's account, which covers the history of the House of 'Osmān, stands as the earliest written account of the early Ottoman polity, on which almost all later historians relied for their versions of early Ottoman history. ${ }^{17}$ Most of the universal history, however, is devoted to the rise of Islam and the history of the Umayyads and the 'Abbasids.

It is hard to call Aḥmedī an Ottoman per se; he was more of a Rumi (i.e., an educated Muslim from Anatolia), like most other literary figures of this century, as his career illustrates. Nonetheless, Ahmedì's section on the history of Islam is still instructive: How did the earliest known historian of the House of 'Osmān treat the early history of Islam and the early Muslim dynasties? Ahmedì's account of the Prophet's life and mission does not seem to differ significantly from other Sunni accounts, even down to the historical inaccuracies. ${ }^{18} \mathrm{He}$ depicts Mu'āwiya very negatively: Mu'āwiya was appointed by the Prophet as a scribe to record his revelations from God, but he betrayed Muhammad's trust and was exiled. When 'Uthmān became caliph, he appointed Mu'āwiya to an important post, and that was why, according to Ahmedī, 'Uthmān was killed. (In reality, Mu'āwiya was appointed by 'Umar). Mu'āwiya was indeed a recorder of revelations (wahy), at least according to most sirāts. However, earlier accounts do not mention his betrayal. Ahmedī, to dramatize Mu'āwiya's actions or, under the influence of the philo-Alid sentiments of the time or, more speculatively, under the influence of a Shi'ite source, makes him a villain, even during the lifetime of the Prophet Muhammad.

\footnotetext{
15 For Aḥmedī’s biography see Ünver, İskendernāme.

16 Ünver, İskendernāme 5-7.

17 İnalcık, The rise of Ottoman historiography 161.

18 The following folio numbers refer to the copy of the İskendernāme preserved in the Istanbul Üniversitesi Nadir Eserler Kütüphanesi, Türkçe Yazmalar, Ms 921. This text is reprinted in a facsimile in Ahmedī, İskendernāme.
} 
Ahmedī describes 'Alī's rule in the context of Mucāwiya's attempts to instigate rebellion against him. He accuses Mu'āwiya of being untrustworthy because he broke his covenant with 'Ali's elder son Hasan, whom he allegedly poisoned. Ahmedī is terse on Mu'āwiya's caliphate. He does not refer to any of Mu'āwiya's achievements or conquests and depicts him as a usurper with no legitimate claim to the leadership of the Islamic community: "Mu'āwiya took the caliphate from 'Alī with 'a thousand sorceries' and betrayed religion." He is called a mütegallibe, someone who became a king by force and without legitimate right (istihkāksuz). ${ }^{19}$ Ahmedì's negative treatment of the descendants of Abī Sufyān continues with Yazīd b. Mu'āwiya, who, according to the poet, has "no share in religion." He depicts him as a tyrant who harmed the public. "Although people say there should be no cursing of him," Aḥmedī avers, "may God's curse be upon him from beginning to end."20 However, he praises Yazīd's son Mu'āwiya II (r. 64/683-684) for abdicating the caliphate; this, Ahmedī feels, is the act of a wise ruler who admits that his family usurped the leadership from 'Alī b. Abī Ṭālib.

A near contemporary of Ahmedī, Yazıcıoğlu Mehmmed's famous mathnawi Risāletü'l-Muhammediye is another significant source on Rumi Muslim religiosity in the early centuries of the Ottoman Empire. This work, known simply as the Muhammediye, enjoyed immense popularity over the centuries. Manuscripts can be found in libraries all over the world, as well as in the private collections of numerous Turkish families who held it sacred like the Quran. ${ }^{21}$ Yazıcıoğlu Mehmed belonged to an erudite family as both he and his brother Aḥmed (Bicān) (d. after 870/1466) became well-known scholars. As he mentions in his work, he was educated by two great scholars of his age: Zeynü'l-'Arab ${ }^{22}$ and Ḥaydar-ı Hafì. ${ }^{23}$ Yazıcıoğlu was also a pupil of the age's great Sufi master, Hācı Bayrām-ı Velī of Ankara (d. 834/1430). Yazıcıŏğlu became acquainted with Velī on the latter's way to Edirne when Velī was summoned

19 Ibid. $57 \mathrm{~b}-58 \mathrm{a}$.

20 Ibid. 58 a.

21 The work's popularity outside the Ottoman domains attests to its wider impact: the Muhammediye was also known among Crimean and Central Asian Turkish populations later in the ninth/fifteenth century. Köprülü, Divan edebiyatı antolojisi 68, cited in Yazıcıoğlu, Muhammediye i, 85; and Bombaci, Histoire de la littérature turque 259. On the reception of the Muhammediye corpus, see the magisterial study by Heinzelmann, Populäre religiöse Literatur. Most recently, Krstić argued that this work should be counted among the 'ilm-i hạal works in terms of authorial intent. Krstić, From shahāda to 'aqìda 299 .

22 Yazıcıoğlu, Muhammediye ii, 6o3, couplet 8973.

23 Ibid., couplet 8974. 
by Sultan Murād II (r. 824-855/1421-1451), based on allegations that he was causing trouble in Ankara and gathering rowdy pupils around him. ${ }^{24}$ After this initial encounter, he submitted himself to Ḥācı Bayrām-ı Velī and became his pupil and eventually one of his adepts. Muhammediye indeed showcases greatly Yazıcıoğlu's Sufi inclinations.

Events following the death of Muhammad are covered rather succinctly in Muhammediye. As for 'Alī, Yazıcıoğlu cites the hadith in which Muhammad likens his relationship with 'Alī to Moses's relationship with Aaron. However, Yazıcıoğlu observes, Mu'āwiya and his followers did not see that 'Alī was a mirror to God, and so they opposed his caliphate and caused him to suffer. Like most authors discussed in this study, Yazıcıoğlu reports a hadith in which the Prophet predicts that the caliphate would last for 30 years after his death but would be followed by kingship (mülk). ${ }^{25}$ Ottoman historians used this hadith to make sense of the end of the line of the Rightly Guided (Räshidūn) caliphs and what all of them regard as the Umayyad usurpation of the caliphate. Yazıcıoğlu adopts the widespread popular practice of cursing Yazìd because of his destruction of the Prophet's grandsons Hasan and Husayn. He explains that cursing Yazìd had been prohibited among the Sunnis in the past but that it has recently come back into vogue. In betraying the family of the Prophet, in any case, Yazīd had fallen into heresy (ilhād) and thus deserved to be cursed. ${ }^{26}$

A few decades later, Şükrullāh also treated early Islamic history in his famous work Bahjat al-tavārïkh. Unlike most other Ottoman historians, he does not speak ill of Mu'āwiya b. Abī Sufyān except to point out that he conspicuously consumed luxuries. He is also reticent about the conflict between him and 'Alī b. Abī Tâlib. However, he includes a summary of the events of Karbala, mostly in line with Abū Mikhnaf and al-Ṭabarī, a source he frequently refers to along with Qüt al-arwāh of Hasan b. 'Alī b. Hammād. He does, however, condemn Mu'āwiya's son Yazīd for the massacre of Husayn and his family at Karbala in 68o. He calls Yazìd "dirty and damned" and points to his wicked character. He heavily criticizes him for drinking openly, introducing castration in Islam, and destroying God's house (Kaba) and the cities of Mecca and Medina. He says that Yazid's demonic and damned body went straight to the lowest level of hell (esfel-i säfilinn). ${ }^{27} \mathrm{He}$ calls Yazĩd's followers Yezìdìs and condemns them with heavy curses for supporting Yazīd and being instrumental in the murder

\footnotetext{
24 Şapolyo, Mezhepler ve tarikatlar 133.

25 Yazıcıŏ̆lu, Muhammediye ii, 303-304, couplets 4635-4645.

26 Ibid. 305, couplets 4667-4669.

27 Almaz, Şükrullah 311-313.
} 
of Husayn. ${ }^{28}$ Apart from a few figures, such as the famously pious 'Umar b. 'Abd al-'Azīz (r. 99-101/717-720), who is widely praised for his devoutness and benevolent treatment of the family of the Prophet, and Hishām b. 'Abd al-Mālik (r. 105-125/723-43), who honored the fifth Shi'ite imam, Muhammad al-Bāqir (d. 114/732), he unflatteringly describes the Umayyads as gluttonous, arrogant, lustful, dull, insensitive, violent, and irreligious.

A contemporary of Şükrullāh, Enverīs famous mathnawi Düstūrnāme also has a few lines on early Islamic history. ${ }^{29}$ Enverī tells us that he dealt with early Islamic history in his now lost Teferrücnāme. He briefly summarizes 'Alì's conflict with 'Ā'isha and her allies, Țalha and Zubayr, and Mu'āwiya's call for arbitration of his struggle with 'Alī. He affirms that Mu'āwiya won over the caliphate with a trick and calls him ssakill, which means both overweight and oppressive (Mu'āwiya was known for his overeating). With regards to Ḥusayn's killing, he again refers his readers to Teferrücnäme. ${ }^{30}$ For Yazīd, he says "he was drowned in the pool of crime."31

How should we assess this apparent animosity toward the Umayyads and especially Yazīd among the early Ottoman writers? The history of the Umayyads was written by 'Abbasid-era historians such as al-Ṭabarī. Therefore, most histories of the Umayyad era are tinged with a strong 'Abbasid bias and sympathy for 'Alī. One could easily argue that early Ottoman intellectuals' view of the early Islamic history is similarly tinged due to their sources. However, their sources were scanty and often incomplete. What shaped their views more than their sources was a tradition that the Ottoman intellectuals cherished. This tradition, which openly venerates ahl al-bayt, first manifested itself in the futuww $a^{32}$

28 As a matter of fact, historical Yazidis are perhaps one of the most scourged groups in the Sunni world up to today. They were subjected to a genocide by the so-called Islamic State in 2014. Even though they have a history that goes back earlier than the establishment of the Umayyad caliphate, some of their significant figures are of Umayyad descent. The term Yazidì as used by the Ottoman historians may not necessarily correspond to the historical Yazidis but rather should be understood as a theoretical group of staunch defenders of the Umayyad caliph Yazīd's caliphate as well as his persona.

29 Mélikoff-Sayar, Le destān d'Umûr Pacha. An earlier edition is [Enverī], Düsturnamei Enveri edited by M.H. Yinanç. For a more recent one, see Öztürk, Fatih devri kaynaklarından. None of the above editions include pre-Islamic sections of the Düstūrnäme. Complete work can be found in İzmir Milli Kütüphane, MS 16114-22/401.

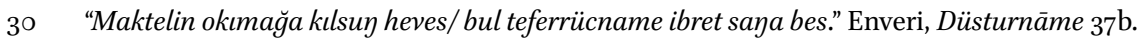

31 "Suç havuzunda boğulur gör nider." Ibid. $37 \mathrm{~b}$.

32 'Alì b. Abi Țālib was seen as the spiritual leader of the futuwwa (urban fraternities) and styled as the ideal youth, or fatā. Various fütüvvetnāmes carry a very strong Shi'ite influence. See Breebaart, The Fütüvvet-nāme-i kebīr 203-215; Loewen, Proper conduct ( $a$ dab) is everything $543^{-570}$; also see Ylldırım, Shī'itization of the futuwwa. Note, however, 
networks and various Sufi groups. ${ }^{33}$ The historians of the Mongols and successor states, such as the Ilkhanids, agree that after the Mongol invasions of the seventh/thirteenth century, confessional ambiguity characterized the religious attitudes of both the political leaders and some of the religious communities. ${ }^{34}$ "To cite only one example, some of the coins of the Timurid ruler Abū al-Qāsim Bābur (r. 853-861/1449-1457) bear Shi'i formulas on one side and Sunni legends on the other." ${ }^{35}$ In this environment, a moderate inclination toward Shi'ism made great strides in Sunni communities. The veneration of not only 'Alī b. Abī Taalib, his wife Fāțima, and his sons Ḥasan and Ḥusayn, but also the entirety of the Shi'ite imams had spread in the dominantly Sunni communities. ${ }^{36}$ This process paved the way for the inextricable linkage of Sufism and Shi'ism in Iran, finally resulting in the birth of the Safavid dynasty. In the remainder of the Sunni lands, on the other hand, it led to a profound veneration for the ahl al-bayt. Many Sunni states capitalized on that sentiment by projecting themselves as sponsors and protectors of Shi'ite shrines in Egypt, Iraq, and Syria. ${ }^{37}$

I believe R.D. McChesney captures this phenomenon best in his study of an 'Alid waqf in Central Asia. ${ }^{38}$ McChesney calls this deep veneration for ahl albayt among the Sunnis "ahl al-baytism." I argue that this is a useful concept to address strong 'Alid loyalty in predominantly Sunni geographies such as the

that 'Ali was not always central to the futuwwa tradition but became more so in the late medieval period; Ylldırım sees the ninth/fifteenth century as a critical turning point, while Lloyd Ridgeon points to some earlier developments as well. See Ridgeon, Morals and mysticism.

33 B.G. Martin argued more than 40 years ago that had Halvetis not been forced by the Ottoman ulama to adopt a Sunni attitude, they could have easily ended up being a Shi'ite tariqa given their early attachment to Shi'ism. Martin, A short history 284. In a recent appraisal of the Halvetis order in the Ottoman Empire, John Curry opposes Martin's argument: "In the end, the inclusion of the six imams of the Shi'ite tradition in the constructed identity of the Halvetī silsile need not be taken as decisive proof of crypto-Shi'ism." Curry, The transformation 25. For an excellent treatment of the relationship between Shi'ism and Sufism, see Nasr, Shi'ism and Sufism.

34 For this phenomenon, which is also called "confessional ambiguity," see Woods, The Aqquyunlu 4-5; Amoretti, Religion in the Timurid 610-655.

35 Woods, The Aqquyunlu 4.

36 See various studies by Riza Ylldırım on eighth/fourteenth- and ninth/fifteenth-century Anatolia for the impact of Shi'ism on the Sunni communities and the interactions between the two: Ylldırım, Beylikler dünyasında; Yıldırım, Abdallar, akıncılar, Bektaşilik; Yıldırım, Anadolu'da İslamiyet; Yıldırım, Sunni orthodoxy vs. Shi'ite heterodoxy.

37 For a recent study of the shrines in Syria, see Mulder, The shrines of the Alids 16-47. For the importance of the cult of 'Alid saints, especially in Fatimid Cairo, see Williams, The cult of 'Alid saints i, 39-6o; ii, 37-52.

38 McChesney, Waqf in Central Asia 33-34, 268. 
Ottoman Empire. Even though McChesney limits ahl al-baytism to 'Alī and his immediate descendants, I include in this concept all of the Twelve Imams. The poets mentioned above, Aḥmedī, Enverī, and Yazıcıoğlu, also exhibited ahl albaytism, especially in their criticisms of Yazìd and the Umayyads. It seems that, in pre-Safavid Anatolia, Shi'ite-tinged readings of early Islamic history were common among intellectual circles. It is also worth noting that all of these writers had Sufi affiliations. Just like it changed the religious landscape in the medieval Islamic world, Sufism also helped shape Ottoman Sunnism by carrying over Sufism's strong 'Alid stance. One could argue, based on Cemal Kafadar's previously mentioned concept of metadoxy, that what I described above is perhaps not surprising. What follows in the next section testifies to the fact that this trend continued unabated despite the sectarian milieu of the tenth/sixteenth century.

\section{Sunnism and Islamic History in the Age of Ottoman-Safavid} Conflict: Perspectives from the Sixteenth Century ${ }^{39}$

The tenth/sixteenth century has been considered a watershed moment for Ottoman Sunnism. Selīm I's (r. 918-926/1512-1520) anti-Kızlbaş campaigns in Anatolia and his rivalry with the nascent Safavid state, as well as Ottoman jurists' continuous efforts to redefine Sunni orthodoxy, are considered clear testaments to that effect. In a recent study, Derin Terzioğlu sketches the history of Ottoman Sunnism and suggests that Ottoman Sunnitization began considerably earlier than the tenth/sixteenth century: "This process (Sunnitization) was a continuation of pre-existing trends, and had complex and multiple causes rather than being simply a politically-minded response to the rise of the Safavids and their adoption of Shi' ism." ${ }^{40}$ Pioneering works of a new generation of scholars, namely Tijana Krstić, Derin Terzioğlu, and Guy Burak, have placed Ottoman efforts at Sunnitization, beginning in the tenth/sixteenth century, within the context of the broader early modern phenomenon of confessionbuilding and confessionalization that they see spanning Europe and the Middle East. ${ }^{41}$ In its original formulation, "confessionalization" refers to the social effects of confession-building projects after the Reformation in Europe and

39 This section is mostly a reiteration of the relevant sections from my article Problematizing Ottoman Sunnism 614-646.

40 Terzioğlu, How to conceptualize 305.

41 Krstić, Contested conversions; Terzioğlu, How to conceptualize; Terzioğlu, Where 'ilm-i hăal; Burak, The second formation; Burak, Faith, law and empire. 
gradual rapprochement between the state and the church. Even though there is a great value in integrating Ottoman (and Safavid) religious landscapes into the broader Eurasian trends, the term confessionalization carries the potential to overemphasize the role of the state and the ulama (the only group that to some extent resembles clergy in Islamic societies) in the formation of religious confessions. ${ }^{42}$ However, it would be incorrect to argue that Sunnitization (or any religious process for that matter) was primarily a state-enforced and state-led policy. I particularly value here the multiplicity of agents and processes argument brought forth by Terzioğlu and expanded by Krstić. ${ }^{43}$

When one considers Ottoman Sunnism, a state-centered religious approach often dominates the narrative. Besides what the state and jurists tell us about Sunnism, what can we learn from the Ottoman historians and intellectuals who penned works on these subjects in the tenth/sixteenth century? Since a rehabilitation of the images of Yazīd and Mu'āwiya was already in place in the seventh/thirteenth century, probably as a reaction to the increasing 'Alidism in Sunni circles, did the Ottoman historians, in their treatments of the succession struggle in early Islamic history, show a pro-Umayyad stance? To address this question, this section will investigate the works of two of the prominent intellectuals of the tenth/sixteenth century: Muștafā Cenābī (d. 999/1590-1591) and Muștafā 'Ālì (d. 1008/1600). ${ }^{44}$

Muștafā Cenābī is the lesser known of the two, even though his work, Aylām $a l-z \bar{a} h i r$, had a substantial impact on a future generation of historians, such as Qaramānī(d. 1019/1611), Kātib Çelebi (d. 1067/1657), and Müneccimbaşı Aḥmed (d. 1113/1702). ${ }^{45}$ Cenābī was himself a sayyid, a descendant of Muhammad, and had great love for the ahl al-bayt. Cenābỉs work includes an extensive treatment of the Twelve Imams. His account of the Shitite imams, as well as his narrative of the different sects of Shi' ism, is clearly inspired by al-Shahrastānì's (d. 548/1153) famous compilation of various religious beliefs, philosophies, and doctrines known as al-Milal wa-l-nihal. ${ }^{46}$ In addition to the Isma'ili-inflected work of al-Shahrastānī, ${ }^{47}$ Cenābī bases this section on Twelver, or Imami, Shi'ite

For a study that emphasizes the role of the Ottoman, state see Krstić, Illuminated by the light.

Terzioğlu, How to conceptualize 320 . See also the recent study on 'aqā’id works by Krstić, where she argues for a similar point of view. Krstić, From shahāda to 'aqīda 296-314.

For more detail on the tenth/sixteenth century, see Erginbaş, The appropriation of Islamic history.

Cenābì, Aylām al-zāhir (the manuscript I am using records the title as al-Hāafil al-wasit wa-l-ayläm al-zähir al-muhịt, which is one of the known variants). The primary study on Mușțafā Cenābī is Canatar, Müverrih Cenābī Muṣțafā.

Al-Shahrastānī, Kitāb al-Milal.

For details, see Erginbaş, Problematizing. 
sources where these are available to him, such as Kitāb al-irshäd of the Twelver theologian, jurist, and polemicist al-Mufìd (d. 413/1022 $)^{48}$ and I İām al-warā bia lāmal-hudā of the Twelver scholar and theologian Abū 'Alī al-Faḍl b. al-Ḥasan al-Tabrisī (d. 548/1153). Cenābī also makes extensive use of Sunni sources on the imams that are known for their sympathies for the ahl al-bayt, so much so that their authors have been dubbed as "Twelver Sunnis" by some modern scholars. $^{49}$ One of these authors, Ibn Țalha wrote his work in Damascus in 649/1252; it became notorious among the Sunni authors of the seventh/thirteenth century since it not only defended the Twelve Imams but also supported the idea that the Twelfth Imam was indeed the eschatological Mahdi. ${ }^{50}$ Cenābì's careful use of both Shi'ite and "ahl al-baytist" Sunni sources shows the extent of his knowledge of the Shi'ite imams and their history, as well as his preference for such sources that support an 'Alid interpretation of early Islamic history.

Cenābī regards the founder of the Umayyad dynasty, Mu'āwiya b. Abī Sufyān, as a mutaghallib, or usurper, and lists a few of his achievements with little comment. He briefly describes his bad temper and weaknesses, such as wearing expensive clothing and riding expensive horses. His only redeeming feature was his skill at politics. He is harder on Yazid, who was responsible for the killing of Ḥusayn b. 'Alī b. Abī Ṭalīb, arguing that he was an infidel because of his poems praising drinking and because of the derisive words that he uttered when Husayn was martyred. ${ }^{51}$ Cenābī's Umayyad section seems to be a very concise précis of al-Ṭabarī's (d. 310/923) account.

Muștafā 'Ālī is possibly the best known of the tenth/sixteenth-century Ottoman intellectuals. His account of the reign of Mu'āwiya b. Abī Sufyān, in his Künhü'l-ahbār ${ }^{52}$ is far superior to other accounts under study here. The author's attitude toward Mu'āwiya appears empathetic at first, but as the narrative continues, a critical stance emerges. Muștafā 'Ālī asserts that Mu'āwiya converted to Islam many years before the Muslim conquest of Mecca in 8/630 but concealed his belief out of fear. He was one of the Companions of the Prophet, for whom the latter prayed for both this world and the hereafter, and on whose authority hadith were transmitted. 'Umar ibn 'Abd al-'Azīz famously defended him. He reportedly saw Mu'āwiya in a dream in which the latter told

48 For al-Mufid and his importance in the Shi'ite revival of the Buyid age, see Kraemer, Humanism in the Renaissance $67-68$.

These works are Al-Fușülal-muhimma fìma'rifat aḥwāl al-a'imma of the Maliki scholar 'Alī ibn Muḥammad ibn al-Ṣabbāgh and Mațālib al-su'ül fì manāqib Āl al-Rasūl of the Shafi'i author Kamāl al-Dīn Muhammad b. Ṭalḥa al-'Adawī al-Niṣībīnì'.

50 Madelung, al-Mahdi.

51 Cenābī, Aylām al-zähir 353b.

$5^{2}$ 'Ālī, Künhül'-ahbārr. 
him that God forgave him for opposing 'Alī. In other dreams reported by anonymous mystics, Mu āwiya sits next to the Prophet Muhammad like the other true companions. Sunni mystics and scholars alike, including the great legist Ahmad b. Hanbal (d. 241/855), saw in their dreams that the Prophet Muhammad condemned people who disparage Mu'āwiya. Muștafā 'Ālī reports a tradition of Jarīr ibn 'Abd al-Hamīd, one of the teachers of Ahmad b. Hanbal, that Mu'āwiya was disconsolate when the news of 'Alī b. Abī Ṭalīb's martyrdom reached him. Mușțafā 'Ālī also refers to Mu'āwiya with honorific titles. Although Mușțafā 'Âlì duly reports on the caliph's vices, such as his love for jewelry and food, for which the Prophet condemned him, as well as his actions against the Prophet's descendants, he also praises him for his raids against the Byzantines, for serving as a scribe to the Prophet, for his generosity, especially toward 'Alī's sons Ḥasan and Ḥusayn, the Prophet's grandchildren, and the Prophet's wife 'Ā'isha, and for his skill in politics and military strategy.

On the other hand, he also provides a critical perspective on Mu'āwiya. In Mușțafā 'Ālī's narrative, Mu'āwiya acknowledges more than once that 'Alī b. Abi Ṭalīb is superior to him and that he did not want to be caliph until after his cousin 'Uthmān b. 'Affān was killed. Mușțafā 'Ālī also includes a critical report of the famous mystic Hasan al-Bașri (d. 110/728) to the effect that there are four of Mu'āwiya's actions that are impossible to justify: his role in 'Alī b. Abī Talīb's murder, his killing of one of the Prophet's companions, his favoritism toward his own family, and his appointment of his son Yazīd as his successor. We also see 'Â'isha, the Prophet's favorite wife, rationalizing Mu'āwiya's caliphate by pointing out that God sometimes bestows power on unbelievers or sinners; after all, He allowed the pharaohs to rule Egypt for centuries. On the conflict between Mu'āwiya and 'Alī b. Abī Talīib, Mușțafâ 'Ālī argues that one should assess it within the context of fate and God's will. However, given the hadith in which the Prophet advises everyone to follow 'Alī b. Abì Talīb, Mu'āwiya should have acknowledged his caliphate. Mușțafā 'Ālī asserts that he cannot understand those who do not comprehend the truths revealed by this hadith and adds that it is impossible to forget that many companions of the Prophet were killed at the battle of Siffin while fighting on the side of 'Alì b. Abī Ṭalīb.

Muștafā 'Ālī's rather ambivalent account of Mu'āwiya b. Abī Sufyān contrasts with his even-handed account of Yazīd b. Mu'āwiya, who is usually regarded in a far more negative light than his father. Muștafā 'Ālī distances himself from narratives praising or disparaging Yazìd and acknowledges that he is aware of hadiths of dubious authenticity in support of both positions. He relates a somewhat positive tradition that in later life Yazīd distanced himself from his protégé, 'Ubayd Allāh b. Ziyād, because of the latter's role in the massacre of 
Ḥusayn b. 'Alī. Another hadith that Mușțafā 'Ālī cites, in contrast, insists that Yazīd was purely one of the denizens of hell. Musțafā 'Ālì indicates his own position by using derogatory terms for Yazīd such as "damned and dirty." He also argues that Yazid's attacks against the people of Mecca and Medina, as well as his brutal treatment of the Prophet's descendants, above all Husayn, are signs of a lack of belief and submission to Islam. Commensurate with his even-handed approach, he also points out Yazīd's good qualities, such as his generosity and intelligence. As in the case of Mu'āwiya b. Abī Sufyān, certain mystics reported dreams in which Yazīd told them that God had forgiven him. Musțafā 'Ālī does not find these reports credible because of Yazìd's actions, which, according to the author, surely proved otherwise. Mușțafā 'Ālī also argues that because of Yazid's atrocities against the descendants of the Prophet, none of his children lived long enough to enjoy this world, although there were among them some righteous people, such as his son Mu'āwiya II.

Muștafā 'Ālī's account of Ḥusayn ibn 'Alī’s life and martyrdom at Karbala is one of the most exhaustive and vibrant sections of Künhüll-ahbār. ${ }^{53}$ Muștafā 'Ālì composed elegies for Ḥusayn and the other eleven imams. His Sübhatü'labdāl, completed in 1000/1593-1594, collects elegies on 'Ashürä', the day of Husayn's martyrdom. ${ }^{54}$ To show his devotion to Husayn, he endowed a fountain in Karbala while serving as interim governor of Baghdad in 993/1586. ${ }^{55}$ Muștafâ 'Álī acknowledges that some of the reports of the extreme Shi'ites concerning blood flowing from stones on the site and the sun bearing a bloodstain on the day of the massacre are not true. On the other hand, he argues that Ibn Athīr is wrong to discourage lamentations for Husayn that go beyond those for the other imams. Mușțafâ 'Âlī justifies the lamentations because, he argues, on no other occasion when an imam was victimized was the Prophet's lineage so gravely endangered.

Cenābī and Muștafā 'Ālī glowingly portray the Shi'ite imams. The latter explicitly states that the descendants of the Prophet Muhammad had a right to the caliphate. He regards the 'Alids as far superior to the Umayyads and evinces a deep devotion to the martyred Husayn. ${ }^{56}$ In its cultural and intellectual representation, Ottoman Sunnism did not show hostility toward the 'Alids and their political cause. The image of Ottoman Sunnism that we have in

\footnotetext{
53 Ālī, Künhül'-ahbār iii, 353-385.

54 Fleischer, Bureaucrat and intellectual 148.

55 Ibid. 124.

$5^{6}$ In his later work known as Curious bits of wisdom, he apparently goes so far as to offer a solution to the Sunni-Shi'i division. Fleischer, Mușțafā 'Alī's Curious 103-109. Unfortunately, I do not have access to the text of Muștafā 'Ālī's work.
} 
our mind is mostly epitomized by Selīm I's anti-Kızllbaş campaigns in Anatolia and strong anti-Safavid rhetoric evident in the writings of the Ottoman jurists such as Kemālpaşazāde (d. 940/1534) and Ebū's-su'ūd (d. 982/1574). However, one has to also remember that Ottoman Sunnism in the most general sense was also imbued with ahl al-baytism and sympathy toward the 'Alid political cause. Both Cenābī's and 'Ālì's works show that despite the ever-growing Safavid influence in Anatolia and Iraq in the late tenth/sixteenth century, and despite a state of open warfare between the Ottoman and Safavid empires, Ottoman intellectuals did not necessarily adopt a rigid Sunnism that legitimized the results of the early succession struggle in Islam. Rather, reverence for the ahl al-bayt remained quite strong among them. Ottoman Sunnism by no means entailed disowning the Shi'ite imams or their legacy; in some cases, it did not even entail rejecting the Shi'ite eschatological doctrine. ${ }^{57}$ The contributions of these two authors point to the strong ahl al-baytist bent in Ottoman Sunnism among the intellectuals in the tenth/sixteenth century.

\section{3}

\section{A More Visible Sunnism or Sunnitization "From Below": Perspectives from the Seventeenth Century}

While the discussion of religiosity in the tenth/sixteenth-century Ottoman Empire revolves around the state-sponsored Sunnization efforts, the Kadizadeli controversy overshadows the eleventh/seventeenth century. One could argue that the puritanical movement of the Kadızadelis represents the peak in a process that Krstić called "confessionalization from below." However, the mere existence of this controversy shows that this Sunnitization process was neither seamless nor universally accepted. In what follows, this section investigates how three intellectuals who wrote sections on Islamic history in their universal histories in the first half of the eleventh/seventeenth century approached the succession issue.

The universal history written in Arabic by Abū al-'Abbās Aḥmad b. Yūsuf b. Aḥmad b. Sinān al-Qaramānī al-Dimashqī, famously known as al-Qaramānī, is entitled Akhbār al-duwal wa-athār al-uwal fì l-tärīkh, and was composed right at the turn of the eleventh/seventeenth century. ${ }^{58}$ Kàtib Çelebi and many others after him describe Akhbār al-duwal as a summary of Cenābī's history with few additions. While it is true that Qaramānī reproduces a great deal of Cenā-

57 See Erginbaş, Problematizing.

$5^{8}$ Al-Qaramānī, Akhbār al-duwal. 
bi's material, his work is not a verbatim copy of the latter's history. In fact, his omissions and additions shed a good deal of light on how he and Cenābī differed in their scholarship and their attitudes toward early Islamic history. Although Qaramānī's work features some of the ahl al-baytist notions of his predecessors, his work strikes one as more Sunni-oriented than Cenābī's work. For instance, he acknowledges at the very beginning of Abū Bakr's reign that he was the best created being after Muhammad according to the Sunnis (ahl al-sunna wa-l-jamā'a), followed by 'Umar, 'Uthmān, and 'Alī. He also praises the greatness of Abu Bakr's 'ilm, or esoteric knowledge, in contrast to other works, which stress Abū Bakr's closeness and loyalty to the Prophet and not his esoteric knowledge. ${ }^{59}$ It is to 'Alī that 'ilm is usually attributed. In keeping with his overall approach, Qaramānī refrains from including much detail on the political aspects of the reigns of the Rāshidūn caliphs, preferring to emphasize their personalities. His aversion to political narrative continues in his treatment of 'Umar's reign; hadiths concerning the caliph's virtues and quasi-miraculous deeds are of greater concern to Qaramānī. ${ }^{60}$ In summarizing 'Uthmān's reign, he asserts that he was killed by "oppressors" and acknowledges that he favored the old-guard Quraysh, who were recent converts to Islam, as opposed to 'Umar, who was harsh toward them. He acquits 'Alī b. Abī Ṭalīb of any complicity in 'Uthmān's murder based on a report recorded in Ibn 'Asākir's history. He provides additional circumstantial details that tend to exonerate 'Alī: 'Alī beat his children because 'Uthmān was killed while they were guarding the door to his house; 'Alī sent water to 'Uthmān while he was under siege. He also includes a glowing report of 'Alī's virtues. He narrates 'Alī's murder based on al-Suyūtị̂s (d. 911/1505) and Ibn 'Asākir's histories and adds a report of 'Alī asserting that he did not see anyone better fit than he was to assume the caliphate when the Prophet died. ${ }^{61}$ Following his account of 'Alī, he presents a narrative of the lives of the twelve imams; from this point on, his history closely parallels that of Cenābī. ${ }^{62}$ Like Cenābī, Qaramānī presents the imams as epitomes of righteousness, justice, and true faith. He focuses on the characters of Hasan and Husayn while avoiding comment on the explosive political issues surrounding their careers.

Qaramānī adopts a more conventional Sunni position regarding Mu āwiya b. Abī Sufyān. He emphasizes Mu'āwiya's generosity and gentleness. He refrains from taking a stand on his dispute with 'Alī b. Abī Ṭalīb, insisting that what hap-

\begin{tabular}{ll}
\hline 59 & Ibid. 91-95. \\
60 & Ibid. 95-98. \\
61 & Ibid. 102-104. \\
62 & Ibid. 105-118.
\end{tabular}


pened between them should be assessed according to their independent reasoning $(i j t i h \bar{a} d)$. For the rest of the Umayyads, Qaramānī is critical. He praises only a few of the Umayyad caliphs, and then only the ones who, in his estimation, followed the "righteous" paths of the four rightly-guided caliphs. The author explicitly states that Yazìd was responsible for the murder of Husayn. ${ }^{63}$ At first, he does not openly curse Yazìd but instead curses "Shamir" (Shimr), who actually killed Husayn. Cursing Yazīd, in the manner of most of the Ottoman historians we have studied, would become a bone of contention between the puritanical Kadızadelis and their opponents in the first half of the eleventh/ seventeenth century. Although Qaramānī lived before this debate emerged, he does comment on the appropriateness of cursing Yazīd in his section on Yazīd's caliphate. He notes that three of the four purported founders of the Sunni legal rites, Abū Hanīfa, Mālik b. Anas, and Ahmad b. Hanbal, agreed on cursing him directly (tașrīh) or indirectly (talwīh). For his own part, Qaramānī prefers cursing Yazìd directly because of his actions, such as hunting cheetahs, playing chess, and drinking and praising alcohol, because he believes these made him an unbeliever. To underline his antipathy toward Yazīd, Qaramānī cites a tradition that the later Umayyad caliph 'Umar b. 'Abd al-'Azìz punished a man with twenty lashes because he called Yazìd amir al-mu'minin (commander of the faithful), a title that should be used only by legitimate caliphs; as well as a tradition of the Prophet claiming that the first man who will alter his sunna, or custom, will be an Umayyad named Yazīd. Yet to balance his account, he includes a counter-opinion of the great theologian Abū Hầmid al-Ghazālì (d. 505/1111), who did not permit the cursing of Yazīd because even though he was a sinner, he was still a Muslim, and it is incumbent upon all Muslims not to curse anyone who submits to God. Al-Ghazālī also maintained that Yazīd did not order the murder of Husayn. ${ }^{64}$ Even though he joined the choir in cursing Yazìd, Qaramānī relied more on mainstream Sunni interpretations of history than Cenābī did. A case in point is the 'Alid claimants to the caliphate. Although he follows Cenābì in his account of the early 'Abbasid caliphs, Qaramānì ignores a number of 'Alid claimants whose efforts to attain the caliphate Cenābī describes in some detail.

A near contemporary of Qaramānī is Meḥmed b. Meḥmed, famously known as Edirnevī. His history Nuhbetü't-tevārīh also includes details on early Islamic history ${ }^{65}$ Edirnevīs work is reminiscent of Lāri’s famous history Mirāàt al-

63 Ibid. 107.

64 Ibid. 130-131. See also McDonald, The life of al-Ghazzālī 71-72.

65 Meḥmed b. Mehmed, Nuhbetü't-tevārīh. 
$a d w \bar{a} r .{ }^{66}$ Since Edirnevī used Lārīs work as his model, his opinions, and his reverence for 'Alī b. Abī Talīb bear a close resemblance to those of Lārī. Edirnevī asserts that 'Ali's virtues are beyond human comprehension as he is the gate of learning whose every word warrants a book. Edirnevī vehemently insists that 'Ali refrained from shedding the blood of his brothers in faith and showed respect to all the companions of the Prophet Muhammad; he acquits 'Alī of 'Uthmān's murder. He narrates Ḥasan's and Ḥusayn's lives in summary form by listing their virtues. He calls Husayn's murderers oppressors. Edirnevī refrains from commenting on Mu'āwiya while portraying Yazīd very negatively. He condemns Yazìd and his men because of their oppression of the people of Mecca and Medina and explicitly blames Yazīd for Husayn's murder, calling him damned (lain) and filthy (palid). He also prays that Yazid gets what he deserves.

The towering intellectual of the eleventh/seventeenth century was Kātib Çelebi. Kātib Çelebi's universal history in Arabic, Fadhlaka, ${ }^{67}$ is composed of many works but mostly follows Cenābī's history. In his treatment of the Rāshidūn, Kātib Çelebi shortens some parts of Cenābīs narrative and expands others. He also makes occasional references to Qaramāni’s Akhbār al-duwal. Abū Bakr's and 'Umar's reigns are briefly summarized. ${ }^{68}$ In his coverage of 'Uthmān's reign, Kātib Çelebi rejects as unreliable a report by Saīid ibn al-Musayyab to the effect that since 'Uthmān favored his relatives, those who disdain him should be excused; Cenābī uses this report to neutralize 'Uthmān's murder. ${ }^{69}$ Although relatively detailed, Kātib Çelebi's account of 'Alī b. Abī Ṭalīb's reign is likewise a précis of the relevant section in Cenābī's chronicle. Like Cenābī, Kātib Çelebi emphasizes 'Alī's virtues. At the end of this section, he raises the question of whether Sunnis consider 'Alī or 'Uthmān more virtuous. Drawing on the scholar and Sufi al-Yāfici (d. $768 / 1367)$, he concludes that there are some Sunnis who regard 'Alī as superior to 'Uthmān; among them are the authoritative sìra author Muhammad b. Ishạa (d.15o/770) and the famous mystic Sufyān al-Thawrī (d. 161/778). Kātib Çelebi does not clarify in Fadhlaka the ranking among the first four caliphs; in Mìzannül-hakk, however, he advises his readers to follow the path of ahl al-sunna wa-l-jamāa. According to the mainstream Sunni position, which was defended by, for example, the sixteenth-century Ottoman scholar Birgivī (Birgili) Meḥmed Efendi (d. 981/1573), the ranking

66 Lārī, Mir'āt al-advār. For more details about Lārī and his work see Erginbaş, The appropriation of Islamic history 111-127.

67 Kātib Çelebi, Fadhlaka.

68 Ibid. 65a-69a.

69 Ibid. 71a. 
among the early caliphs follows the historical sequence, that is, Abū Bakr comes first, followed by 'Umar, 'Uthmān, and 'Alī. After them in virtuousness come the rest of the Prophet's companions, then the companions' followers, then the followers of the followers. ${ }^{70}$

Kātib Çelebi renders Ḥasan's and Ḥusayn's biographies briefly, without commenting on their distinctive virtues. Unlike the earlier Ottoman historians, apart from Qaramānī, he does not provide biographies of the remaining Shi' ite imams. The ahl al-baytist narrative, which was very much present in Cenābỉs history, turns into a dry summary of events in Kātib Çelebi's work. Like Qaramānī but unlike Cenābī, Kătib Çelebi often weeds out 'Alid rivals to the Umayyads' and 'Abbasids' rule. Although he might have opted for this method to keep his work short, Kātib Çelebi seems to have been heavily influenced by the conflicts between the Kadızadelis and the Sufis. His choice of a more conventionally Sunni view of events was a consequence of how he approached this conflict. ${ }^{71}$

Since Kātib Çelebi uses Ibn Khaldūn's (d. 8o8/1406) work extensively, it is appropriate here to discuss how Ibn Khaldūn interprets the succession problem in early Islamic history and whether his interpretation differs from Kātib Çelebi's. Ibn Khaldūn's view of the issue of succession to Muhammad reflects what might be called a conventional Sunni position. He favors the Umayyads because they represented group feeling ('asabiyya) at the time, the only thing that prevented the splitting of the Muslim community. He acknowledges the wickedness of Yazīd b. Mu'āwiya, who is accused of the murder of Husayn b. 'Alī, the Prophet's grandson. However, he finds Husayn faulty in his judgment (although he considers him a martyr because of his good intentions) because he opposed the group feeling that was strong among the Umayyads. ${ }^{72}$ Kātib Çelebi adopts a similar outlook on this matter although he does not agree that Husayn erred in his judgment. He does not openly criticize and curse Yazīd, but he does not refrain from discussing his wickedness. He acknowledges that there is a controversy over cursing Yazìd. He adds that the Prophet banned Muslims from cursing fellow Muslims who pray five times a day; Yazīd was known to be a Muslim who prayed. He also mentions alternative views, such as that of the mystic Ibn 'Arabī (d. 638/1240), who allowed such cursing based on the fact that Yazid's acts cannot be considered the acts of a true Muslim.

In an interesting section at the end of his Fadhlaka, Kātib Çelebi includes Yazīd in a list of history's notorious debauchers and oppressors; however, he

$70 \quad$ Imam Birgivi, The path of Muhammad 87.

71 Kâtip Çelebi, Mîzanül'-hakk 61-64.

72 Ibn Khaldûn, The Muqaddimah 425-438. 
does not comment on this elsewhere in the work. In his famous treatise Miz $\bar{a}$ $n \ddot{u} l-h a k k$, however, he explains the issue in some detail. This book discusses 21 issues that were controversial in Kātib Çelebi's lifetime, such as the propriety of Sufi lodges, singing and whirling in Sufi rituals, using tobacco and coffee, the faith of the Prophet's parents, and Ibn 'Arabì's concept of the "unity of being." After discussing each of these issues, Kātib Çelebi reveals his own position. He wrote his book in an attempt to curb the hostilities between the Kadızadelis and the followers of the Halveti Sufi leader 'Abdü'l-mecīd Sivāsī Efendi (d. 1049/1639). The Kadızadelis took their name from Kāạīzāde Mehmed Efendi (d. 1045/1635), a onetime teacher of Kātib Çelebi, who, as a young man admired his preaching. Kādīizāde is said to have been an eloquent preacher who attracted a huge following. (The Kadızadelis adopted a shorter, more basic work by Birgivī, known simply as the Risāle, as a sort of proof text.) Both authors were known as being rigid followers of the Sunni path who did not criticize Sufi practices that were in conformity with the ones of the Prophet but opposed innovations to Islamic practice at the time of the Prophet Muhammad. Like the Damascene jurist Ibn Taymiyya (d. 728/1328) and similar early traditionalist figures, ${ }^{73}$ they came into conflict with certain Sufi orders of whose religious practices they vehemently disapproved.

During Kātib Çelebi's lifetime and in the second half of the eleventh/seventeenth century, the Kadizadelis' struggle against particular Sufi orders frequently took the form of physical conflict, which created turmoil in the Ottoman capital. A particular target of Kadızadeli preaching and activism were the followers of the aforementioned 'Abdü'l-mecīd Sivāsī Efendi, a Halveti shaykh who also enjoyed a large following, including many members of the imperial court. Like Kâḍizāde Mehmed, he was a Friday preacher in one of the biggest mosques in Istanbul. As opposed to Kâdịizāde Mehmed's literal reading of the Quran and other religious texts, Sivāsī argued that there was an esoteric path to knowledge of God that could be attained only by a select few who chose to follow the Sufi path. Although both groups considered themselves followers of

73 It has long been thought that Birgivī used Ibn Taymiyya's work extensively in his treatises; however, a growing number of recent studies argue that this was not the case. Yüksel, Mehmed Birgivi 148; Ivanyi, Virtue, piety and the law 39, 81-82; El-Rouayheb, From Ibn Ḥajar al-Haytamī 303; Terzioğlu, Bir tercüme ve intihal; Radtke, Birgiwī’s Ṭarīqa Muhammadiyya 159-174. For a contrary perspective, see Sheikh, Ottoman puritanism. For an extensive treatment of Ibn Taymiyya in the Ottoman context as well as an analysis of his impact on the Kadızadelis, see Derin Terzioğlu's article in this volume. Terzioğlu argues that there is insufficient evidence to claim that Kadızadelis were significantly influenced by Ibn Taymiyya. 
the Sunni path, Sivāsì's view was more lax in matters concerning religion and society. ${ }^{74}$ In later life, Kātib Çelebi distanced himself from Ḳăḍizāade Meḥmed, especially because he did not approve of the Kadizadelis' opposition to the rational sciences and philosophy, which Kātib Çelebi believed were essential. According to Kātib Çelebi, both the Kadızadelis and the followers of Sivāsì benefited from the controversy and encouraged it to fuel their notoriety.

One of the issues that split the Kadızadelis and the Sufis was cursing Yazid ibn Mu'âwiya. The very fact that such a controversy existed suggests that many Ottoman subjects had adopted the practice of cursing. ${ }^{75}$ The Kadizadelis' spiritual guide, Birgivī Meḥmed, disapproved of such cursing in general because it is not permissible to curse someone who did not die as an infidel; he lists many hadiths forbidding this practice. He does not, however, specify whether Muslims can curse Yazīd. ${ }^{76}$ In Mìzānül'-haḳk, Kātib Çelebi summarizes this controversy and cites different views. He categorically forbids Muslims from cursing Mu'āwiya because he was a companion of the Prophet, and a mujtahid. Any disagreement among them is a matter of ijtihād (independent reasoning); a companion who is proven wrong in his reasoning receives a reward in the afterlife for his intention, whereas one who is proven right receives twice the reward. Although 'Alī was right and Mu'āwiya wrong in the dispute between them, they both deserve credit because they were both companions of Muhammad. This is the same position that Kătib Çelebi takes in Fadhlaka. ${ }^{77}$ As for Yazīd, Kātib Çelebi notes that there are conflicting views. Shi'ites and some Sunnis, such as the Shafi'i jurist Muhammad al-Kiya alHarrāsī (d. 504/1111) and Sa'ad al-Dīn Taftāzānī (d. 792/1389) allow cursing him. But the majority of Sunnis, including al-Ghazālī, do not approve of cursing Yazīd. (He also includes this report of al-Ghazālī in Fadhlaka.) According to Kātib Çelebi, most people curse Yazīd not because they revere 'Alī or abhor Mu'āwiya but because they imitate other people who curse; he points out that using Yazid's name in vulgar curses has become a popular practice. A matter such as this, which has been around for a millennium, should be put to rest; people who follow the middle path, which Kātib Çelebi clearly believes is the correct path, should heed al-Ghazālì's warnings and stay out

74 On the Kadızadeli movement, see Zilfi, The politics of piety 129-183; Zilfi, The Kadızadelis 251-269; Çavuşoğlu, The Kăạīzādeli movement; Baer, Honored by the glory 62-77; Baer, Death in the hippodrome 77-80; Le Gall, Ḳāḍizādelis, Nakşbendis, and intra-Sufi diatribe $1-5$.

75 Niyāzì-i Mıșrī (d. 1105/1694), who was also a Halveti, was one of those Sufis who in his treatises allowed the cursing of Yazīd. Çavuşoğlu, The Kăạīzādeli movement 282-283.

76 Imam Birgivi, The path of Muhammad 246-248.

77 Kātib Çelebi, Fadhlaka 76a-b. 
of the affair. These ideas reflect Kātib Çelebi's overall attitude toward the conflicts in the early Islamic community. In Fadhlaka and other works, he adopts a conciliatory attitude toward matters such as this and encourages his readers to stay away from controversy and public dispute, which he deems futile.

One can observe Kātib Çelebi's "middle path" policy in his section on the Umayyad caliphs. Since Cenābī disapproved of the Umayyads and summarized their reigns only very briefly, Kātib Çelebi relies on Qaramānì's Akhbār al-duwal in this section, although he does not quote it extensively. Unlike Ottoman historians of the previous century discussed in this study, he is not very critical of the Umayyads. Of course, rulers who were upright and devout, such as 'Umar b. 'Abd al-'Azīz or Yazīd b. al-Walīd, are given special treatment, as they are in earlier histories. The remaining Umayyads, however, are not disparaged.

Although the historians of the first half of the eleventh/seventeenth century relied on their predecessors for much of their coverage, they were selective in adopting their predecessors' interpretations and analysis. For example, since Edirnevī relied on Lārì's work, he adopted Lārī's ahl al-baytist attitude. Qaramānī, on the other hand, adopted a more visibly Sunni outlook toward matters in early Islamic history while still honoring some of the ahl al-baytist notions of his main source, Cenābī. Kātib Çelebi, in contrast, stripped Cenābī's account of its pronounced ahl al-baytism and presented a more conventional Sunni reading of early Islamic history. A close reading of these eleventh/seventeenthcentury historians' takes on early Islamic history reveals the complexity of Ottoman Sunnism. One could argue that in the eleventh/seventeenth century a more visibly Sunni outlook, which was more sympathetic toward Mu'āwiya and Yazīd, was apparent in the works of Ottoman intellectuals if one is to judge it from the evidence presented here.

\section{4}

\section{Conclusion}

This chapter argues that when one studies Ottoman Sunnism, one must pay close attention to the phenomenon of ahl al-baytism. In the period discussed here, we can define ahl al-baytism as a belief in the spiritual superiority of ahl al-bayt as well as a clear preference for the 'Alids over the Umayyads in political authority. An often-made critique against this argument is the fact that Sunnism has always included love for the ahl al-bayt. Although Sunni attitudes toward 'Alī and his descendants varied across time and space, there existed a strong current within Sunnism that continued to honor the ranking of the first 
four caliphs and argued that Abū Bakr is the worthiest of all, followed by 'Umar, 'Uthmān, and 'Alī. What is more, Sunni apologists, such as al-Ghazālī and Ibn 'Asākir, among others, found ways to justify Umayyad rule or problematic figures like Mu'āwiya and Yazīd.

The majority of the Ottoman historians studied here shared a visceral distaste for the Umayyads and upheld the 'Alid lineage's right to rule. They described the Twelve Imams no differently than most Shi'ites, even though they rejected some of the extraordinary deeds or qualities attributed to them by the extreme Shi'ites. Some among them, such as Muștafā 'Ālī, mostly under the influence of the so-called "Twelver Sunni" intellectuals of the seventh/thirteenth century, argued that the twelfth imam is indeed the expected Mahdi, who would eventually come back and restore justice in the world. There were a wide variety of opinions on the early succession problem; some Ottoman historians openly criticized Mu'āwiya for opposing 'Alī, whereas some hesitated. They argued that Mu'âwiya was a companion of Muhammad, and it would be wrong for a Muslim to criticize one of the companions of Muhammad. Almost all of them cursed Yazīd and found him unjust and oppressive, and they questioned his sincerity. Some, however, like Kātib Çelebi discouraged people from cursing. One can presume from the given historical evidence that the Ottomans were aware of both ahl-al-baytist and Damascene traditions, particularly the one that Ibn 'Asākir promoted about Mu'āwiya that emerged out of the medieval period. The Ottoman historians selectively used these sources to support the views that they found most befitting their 'Alid or pro-Mu'āwiya positions; and most were clearly 'Alid-tinged. From the chronological evidence, one could argue that ahl al-baytism was strong in the first two centuries of the Ottoman rule, and this continued in the tenth/sixteenth century without interruption despite the sectarian milieu created by the Ottoman-Safavid conflict. One could argue that the eleventh/seventeenth-century historians were more divided on the issue; whether this was due to the Kadizadeli influence, or a selective emphasis given to some of their sources, remains to be seen until more studies like this one are undertaken. All the evidence presented here, however, points to the strong ahl al-baytist bent in the broader framework of Ottoman Sunnism, if one takes the Ottoman historians' interpretation of early Islamic succession struggle between the 'Alids and the Umayyads as a measuring test. 


\section{Bibliography}

\section{Primary Sources (Published and Unpublished)}

Abū Mikhnaf, Maqtal al-Ḥsayn wa-mașra'ahl baytihi wa-așhābihifi Karbalä,'al-mushtahar bi-Maqtal AbīMikhnaf, Kuwait City 1987.

Abū Mikhnaf, The event of Taff: The earliest historical account of the tragedy of Karbala, ed. M.H.Y. al-Gharawi and trans. U. Komo, Qom 2012.

Aḥmedī, İskendernāme: İnceleme-tıpkıbasım, ed. İ. Ünver, Ankara 1983.

'Ālī, M., Künhü'l-ahbār, 5 vols., Istanbul 1277 [1861].

Almaz, H. (ed. and trans.), Şükrullah b. Şihâbeddîn Ahmed b. Zeyneddîn Zekî. Behcetü'ttevârîh (inceleme-metin-tercüme), $\mathrm{PhD}$ diss., Ankara Üniversitesi 2004.

Cenābī, M., al-Ḥāfil al-wasịt wa-l-'aylām al-ẓāhir al-muhịṭ, Süleymaniye Kütüphanesi, Ms Murad Molla 1429.

Edirnevī, Meḥmed b. Meḥmed, Nuhbetü't-tevārīh, Süleymaniye Kütüphanesi, Ms Halet Efendi 589 .

[Enverī], Düsturnamei Enveri, ed. M.H. Yinanç, Istanbul 1928.

Enverī, Düsturnāme, İzmir Milli Kütüphanesi, MS 16114-22/401.

Ibn Khaldûn, The Muqaddimah, trans. F. Rosenthal, Princeton 1967.

Imam Birgivi, The path of Muhammad: A book on Islamic morals and ethics (al-Tariqah al-Muhammadiyyah), ed. T. Bayrak, Bloomington 2005.

Kātib Çelebi, Fadhlakat aqwāl al-akhyār fi 'ilm al-tārīkh wa'l-akhbār, Beyazıt Devlet Kütüphanesi, Ms 1038.

Kâtip Çelebi, Mîzanü'l-hakkfì ihtiyari'l-ahakk, ed. O.Ş. Gökyay, Istanbul 1972.

Lārī, M., Mir'ātal-advārva-mirqātal-akhbār, Süleymaniye Kütüphanesi, Ms Pertev Paşa 479 .

Mélikoff-Sayar, I. (ed. and trans.), Le Destān d'Umûr Pacha (Düsturnāme-iEnverī):Texte, traduction et notes, Paris 1954.

Öztürk, N. (ed.), Fatih devri kaynaklarından Düsturname-i Enverī: Osmanlı kısmı (12991466), Istanbul 2003.

al-Qaramānī, Akhbār al-duwalwa-athār al-uwalfí l-tārīkh, Beirut, Cairo, Damascus n.d. al-Shahrastānī, Kitāb al-Milal wa-l-nihal: Book of religious and philosophical sects, ed. W. Cureton, London 1842-1846.

al-Shahrastānī, Livres des religions et des sects, trans. D. Gimaret, G. Monnot and J. Jolivet, i, Paris 1986; ii, Paris 1993.

al-Ṭabarī, The history of Al-Ṭabarī, xviii, Between the civilwars: The caliphate of Mu'āwiya, trans. M.G. Morony, Albany 1987.

al-Ṭabarī, The history of Al-Ṭabarī, xix, The caliphate of Yazīd b. Mu'āwiya, trans. I.K.A. Howard, Albany 199 .

Yazıcıŏ̆lu, M., Muhammediye, ed. A. Çelebioğlu, 2 vols., Istanbul 1996. 


\section{Secondary Sources}

Algar, H., Caliphs and caliphate, in EIr, iv, 677-679

Amoretti, B.S., Religion in the Timurid and Safavid periods, in P. Jackson and L. Lockhart (eds.), Cambridge history of Iran, vi, Timurid and Safavid periods, Cambridge 1986, 610-655.

Baer, M., Honored by the glory of Islam: Conversion and conquest in Ottoman Europe, Oxford 2008.

Baer, M., Death in the Hippodrome: Sexual politics and legal culture in the reign of Mehmet IV, in Past and present 210 (2011), 61-91.

Baş, E., İbn Asâkir ve Târîhu Dımeşk'i üzerine, in Ankara üniversitesi ilahiyat fakültesi dergisi 39 (1999), 691-706.

Blankenship, K.Y., The end of the jihad state: The reign of Hisham ibn Abd al-Malik and the collapse of the Umayyads, Albany 1994.

Breebaart, D.A., The Fütüvvet-nāme-i kebīr. A manual on Turkish guilds, in JESHO 15 (1972), 203-215.

Bombaci, A., Histoire de la littérature turque, Paris 1968.

Burak, G., Faith, law and empire in the Ottoman "age of confessionalization" (fifteenthseventeenth centuries): the case of "renewal of faith" in Mediterranean historical review 28 (2013), 1-23.

Burak, G., The second formation of Islamic law: The Hanafi school in the early modern Ottoman Empire. Cambridge 2015.

Canatar, M., Müverrih Cenābī Muṣṭafā Efendi ve Cenābī Tarihi, PhD diss., Ankara Üniversitesi 1993 .

Çavuşoğlu, S., The Kạạīzādeli movement: An attempt of Şeri'at-minded reform in the Ottoman Empire, PhD diss., Princeton University 1990.

Curry, J.J., The transformation of Muslim mystical thought in the Ottoman Empire: The rise of the Halveti order, 1350-1650, Edinburgh 2008.

Erginbaş, V., Problematizing Ottoman Sunnism: Appropriation of Islamic history and ahl al-baytism in Ottoman literary and historical writing in the sixteenth century, in JESHO 6 o (2017), 614-646.

Erginbaş, V., The appropriation of Islamic history and ahl-al-baytism in Ottoman historical writing, 1300-1650, PhD diss., The Ohio State University 2013.

Fleischer, C., Bureaucrat and intellectual in the Ottoman Empire: The historian Muștafā 'Alī, 1541-1600, Princeton 1986.

Fleischer, C., Mușțafā 'Alī's Curious bits of wisdom, in WZKM 76 (1986), 103-109.

Goldziher, I., Muslim studies (Muhammadanische Studien), 2 vols., ed. S.M. Stern and trans. C.R. Barber and S.M. Stern, Albany 1971.

El-Hibri, T., Reinterpreting Islamic historiography: Harun al-Rashid and the narrative of the Abbasid caliphate, Cambridge 2007.

Heinzelmann, T., Populäre religiöse Literatur und Buchkultur im Osmanischen Reich Eine Studie zur Nutzung der Werke der Brüder Yazıcıoġı, Würzburg 2015. 
İnalcık, H., The rise of Ottoman historiography, in B. Lewis and P.M. Holt (eds.), Historians of the Middle East, London 1962, 152-167.

Ivanyi, K.A., Virtue, piety and the law: A study of Birgivī Meḥmed Efendī's al-Ṭarīqa alMuhammadiyya, PhD diss., Princeton University 2012.

Kafadar, C., Between two worlds: The construction of the Ottoman state, Berkeley, Los Angeles 1995 .

Khalek, N., Early Islamic history reimagined: The biography of 'Umar ibn 'Abd al-'Azīz in Ibn 'Asākir's Tārīkh madīnat Dimashq, in JAOS 134 (2014), 431-451.

Köprülü, F., Divan edebiyatı antolojisi, Istanbul 1934.

Kraemer, J.L., Humanism in the Renaissance of Islam: The cultural revival during the Buyid age, Leiden 1992.

Krstić, T., Contested conversions to Islam: Narratives of religious change in the early modern Ottoman Empire, Palo Alto 2011.

Krstić, T., Illuminated by the light of Islam and the glory of the Ottoman sultanate: Selfnarratives of conversion to Islam in the age of confessionalization, in Comparative studies in society and history 51 (2009), 35-63.

Krstić, T., From shahāda to 'aqìda: Conversion to Islam, catechization, and Sunnitization in sixteenth-century Ottoman Rumeli, in A.C.S. Peacock (ed.), Islamisation: Comparative perspectives from history, Edinburgh 2017, 296-314.

Krstić, T., State and religion, "Sunnitization" and "confessionalism" in Süleyman's time, in P. Fodor (ed.), The Battle for Central Europe: The siege of Szigetvár and the death of Süleyman the Magnificent's and Nicholas Zrínyi (1566), Leiden, Boston, Budapest 2019, 65-92.

Le Gall, D., Kạḍ̄izādelis, Nakşbendis, and intra-Sufi diatribe in the seventeenth century Istanbul, The Turkish studies association journal 28 (2004), 1-28.

Lindsay, J., Caliphal and moral exemplar? 'Alī Ibn 'Asākir's portrait of Yazīd b. Mu'āwiya, in Der Islam 74 (1997), 250-278.

Loewen, A., Proper conduct (adab) is everything: The Futuwwat-nāmah-i sulțāni of Husayn Vaciz-i Kashifi, $\operatorname{Ir} S_{3} 6$ (2003), 543-570.

Madelung, W., al-Mahdi, in $E I^{2}$.

Martin, B.G., A short history of the Halwati order of dervishes, in Nikki R. Keddie (ed.), Scholars, saints, and Sufis: Muslim religious institutions in the Middle East since 1500, Berkeley 1972, 275-307.

McChesney, R.D., Waqf in Central Asia: Four hundred years in the history of a Muslim shrine, 1480-1889, Princeton 1991.

McDonald, D.B., The life of al-Ghazzālī, with a special reference to his religious experiences and opinions, in JOAS 20 (1899), 71-132.

Mulder, S., The shrines of the 'Alids in medieval Syria: Sunnis, Shi'is and the architecture of coexistence, Edinburgh 2014.

Mulder, S., Abdülhamid and the Alids: Ottoman patronage of "Shi'i" shrines in the cemetery of Bāb al-Ṣaghīr in Damascus, in SI 108 (2013), 16-47. 
Nasr, S.H., Shi'ism and Sufism: Their relationship in essence and in history, in Religious studies 6 (1970), 229-242.

Newman, A.J., Safavid Iran: The rebirth of a Persian empire, London 2006.

Ocak, A.Y., Osmanlı toplumunda zındıklar ve mülhidler: 15.-17. yüzyıllar, Istanbul 1998.

Pellat, C., Le culte de Mu'āwiya au IIIe siècle de l'hégire, in SI 6 (1956), 53-66.

Radtke, B., Birgiwìs Ṭarīqa muḥammadiyya: Einige Bemerkungen und Überlegungen, in Journal of Turkish studies/Türklük Bilgisi Araştırmaları (TUBA) 26 (2002), 159174.

Ridgeon, L., Morals and mysticism in Persian Sufism: A history of Sufi-futuwwat in Iran, Abingdon, New York 2010.

Robinson, C.F., Islamic historiography, Cambridge 2003.

El-Rouayheb, K., From Ibn Ḥajar al-Haytamī (d. 1566) to Khayr al-Dīn al-Ālūsī (d. 1899): Changing views of Ibn Taymiyya amongst Sunni Islamic scholars, in S. Ahmed and Y. Rapoport (eds.), Ibn Taymiyya and his times, Karachi 2010, 269-318.

Sawyer, C.G., Alexander, history, and piety: A study of Ahmedìs 14th-century Ottoman Iskendernāme, PhD diss., Columbia University 1997.

Sheikh, M., Ottoman puritanism and its discontents, Oxford 2016.

Stanfield-Johnson, R., The Tabarra'iyan and the early Safavids, in Iranian studies (2004), 47-71.

Stewart, D.J., The lost biography of Baha' al-Din al-'Amili and the reign of Shah Isma'il II in Safavid, in Iranian studies 31 (1998), 177-205.

Şapolyo, E.B., Mezheplerve tarikatlar tarihi, Istanbul 1964.

Terzioğlu, D., How to conceptualize Ottoman Sunnitization: A historiographical discussion, in Turcica 44 (2012-2013), 301-338.

Terzioğlu, D., Bir tercüme ve bir intihal vakası: Ya da İbn Teymiyye’nin Siyasetü’ş Şer ‘iy$y e$ 'sini kim(ler) Osmanlıcaya nasıl aktardı? in Journal of Turkish studies/Türklük bilgisi araştırmaları 31 (2007), 247-245.

Williams, C., The cult of 'Alid saints in the Fatimid monuments of Cairo. Part I: The mosque of al Aqmar, Muqarnas 1 (1983), 37-52.

Williams, C., The cult of 'Alid saints in the Fatimid monuments of Cairo. Part II: The mausolea, Muqarnas 3 (1985), 39-6o.

Woods, J., The Aqquyunlu: Clan, confederation, empire, rev. and ex., Salt Lake City 1999.

Yıldırım, R., Sunni orthodoxy vs Shi'ite heterodoxy?: A reappraisal of Islamic piety in medieval Anatolia, in A.C.S. Peacock, B. De Nicola and S.N. Yıldız (eds.), Islam and Christianity in medieval Anatolia, London 2015, 278-307.

Yıldırım, R., Abdallar, akıncılar, Bektaşîlik ve ehl-i beyt sevgisi: Yemînî'nin Muhiti ve meşrebi üzerine notlar, in Belleten 75 (2011), 51-85.

Yıldırım, R., Beylikler dünyasında Kerbela kültürü ve ehli-i beyt sevgisi: 1362 yllında Kastamonu'da yazılan bir Maktel'in düşündürdükleri, in Kuzey Anadolu'da beylikler dönemi sempozyumu: Bildiriler, Çankırı 2012, 344-372. 
Yıldırım, R., Anadolu'da İslâmiyet: Gaziler çağında (XıI.-XIV. Asırlar) Türkmen İslâm yorumunun Sünnî-Alevî niteliği üzerine bazı değerlendirmeler, in Jos 43 (2014), 93124.

Yüksel, E., Mehmed Birgivi'nin (929-981 1523-1573) dini ve siyasi görüşleri, Ankara 2011.

Zilfi, M., The politics of piety: The Ottoman ulema in the postclassical age (1600-1800) Minneapolis 1988.

Zilfi, M., The Kạḍīzādelis: Discordant revivalism in seventeenth-century Istanbul, in JNES 45 (1986), 251-269. 